\title{
ATTEMPTED INDUCTION OF IMPLANTATION IN OVARIECTOMIZED MICE WITH OESTRADIOL AND MAST CELL FACTORS
}

\author{
K. W. HUMPHREY \\ Department of Veterinary Physiology, University of Sydney, \\ N.S.W., Australia \\ (Received 27th Fune 1967)
}

Oestrogens are essential for implantation in progesterone-treated, ovariectomized rats and mice (Psychoyos, 1961; Humphrey, 1967). It has been suggested that oestrogens induce blastocyst nidation by releasing histamine and perhaps other mast cell factors (Shelesnyak, 1963). If this is so, then it would be expected that mast cell factors and substances that cause their release (histamine liberators, Paton, 1957) should be as effective as oestrogens in inducing implantation, and that oestrogen-induced implantations should be affected by antihistamines and by changes in the tissue levels of histamine. The dependence of delayed blastocysts on mast cell or adrenal factors was investigated in the following experiments.

Randomly bred mice of the QS strain received gonadotrophins to induce ovulation and mating; the day of finding the vaginal plug was termed Day 1 of pregnancy. The mated mice were ovariectomized between 15.00 and 18.00 hours on Day 3, and received $1.0 \mathrm{mg} /$ day of progesterone in oil until killed on Day 10, when the reproductive tract was examined for implants or free blastocysts. At 12.00 hours on Day 6, some mice received a single subcutaneous injection of various substances. These were oestradiol in peanut oil; the mast cell factors, histamine (diphosphate and dihydrochloride), heparin, 5-hydroxytryptamine (creatinine sulphate); cortrophin ZN (ACTH prepared from hog pituitary, Organon Laboratories), cortisol acetate and the histamine liberators, compound 48/80 and Polymyxin B (given intraperitoneally) all administered in saline. The results in Table 1 show that $0.025 \mu \mathrm{g}$ of oestradiol induced implantation in $90 \%$ of mice but all other treatments were ineffective. Other mice received $250 \mu \mathrm{g}$ of histamine, $50 \mu \mathrm{g}$ of compound $48 / 80$ or $100 \mu \mathrm{g}$ of Polymyxin B on Day 4 (16.00 hours), Day 5 (09.00 and 16.00 hours) and Day 6 (11.00 hours) to increase or decrease the tissue histamine levels artificially (Banik, Kobayashi \& Ketchel, 1963; Humphrey, 1966). Such treatment did not prevent oestradiol-induced implantation (Table 2). Cortisol or cortrophin ZN or the antihistamine, Mepyramine, given at 11.00 hours on Day 6 only or on Days 6 to 9, did not prevent oestradiol-induced implantation or embryonic development (Table 2). 
Implantation of delayed blastocysts in ovariectomized mice is not induced by mast cell factors or histamine liberators, nor is oestradiol-induced implantation prevented by prior depletion of tissue histamine nor by treatment with mepyramine or histamine. Other reports on decidualization in histamine-

TABLE 1

ATTEMPTED INDUGTION OF IMPLANTATION IN OVARIEGTOMIZED MICE BY VARIOUS SUBSTANGES

\begin{tabular}{|c|c|c|c|c|c|c|}
\hline $\begin{array}{l}\text { Treatment on } \\
\quad \text { Day } 6\end{array}$ & Dose & $\begin{array}{c}\text { No. of } \\
\text { mice }\end{array}$ & & & & $\begin{array}{l}\text { with } \\
\text { blants }\end{array}$ \\
\hline $\begin{array}{l}\text { Saline } \\
\text { Histamine dihydrochloride } \\
\text { Histamine diphosphate } \\
\text { Heparin } \\
\text { 5-Hydroxytryptamine } \\
\text { Compound 48/80 } \\
\text { Polymyxin B } \\
\text { Cortisol } \\
\text { Cortrophin ZN } \\
\text { Oestradiol }\end{array}$ & $\begin{array}{r}0.1 \mathrm{ml} \\
1.0 \mathrm{mg} \\
2.0 \mathrm{mg} \\
2.0 \mathrm{mg} \\
2.5 \mathrm{mg} \\
10.0 \mathrm{mg} \\
5.0 \mathrm{mg} \\
50.0 \mu \mathrm{g} \\
100.0 \mu \mathrm{g} \\
1.0 \mathrm{mg} \\
1.0 \mathrm{i.u} . \\
0.25 \mu \mathrm{g}\end{array}$ & $\begin{array}{r}24 \\
8 \\
5 \\
8 \\
7 \\
3 \\
8 \\
7 \\
7 \\
7 \\
8 \\
30\end{array}$ & $\begin{array}{r}70 \cdot 8 \\
75 \cdot 0 \\
80 \cdot 0 \\
75 \cdot 0 \\
57 \cdot 1 \\
66 \cdot 7 \\
87 \cdot 5 \\
57 \cdot 1 \\
71 \cdot 4 \\
57 \cdot 1 \\
75 \cdot 0 \\
3 \cdot 3\end{array}$ & $\begin{array}{l}(4 \cdot 9)^{*} \\
(3 \cdot 7) \\
(4 \cdot 0) \\
(3 \cdot 5) \\
(7 \cdot 3) \\
(3 \cdot 5) \\
(4 \cdot 1) \\
(3 \cdot 3) \\
(4 \cdot 0) \\
(3 \cdot 3) \\
(3 \cdot 5) \\
(5 \cdot 0)\end{array}$ & $\begin{array}{l}0 \\
0 \\
0 \\
0 \\
0 \\
0 \\
0 \\
0 \\
0 \\
0 \\
0 \\
90\end{array}$ & $\begin{array}{l}(0 \cdot 0)^{*} \\
(0 \cdot 0) \\
(0 \cdot 0) \\
(0 \cdot 0) \\
(0 \cdot 0) \\
(0 \cdot 0) \\
(0 \cdot 0) \\
(0 \cdot 0) \\
(0 \cdot 0) \\
(0 \cdot 0) \\
(0 \cdot 0) \\
(11 \cdot 4)\end{array}$ \\
\hline
\end{tabular}

Pregnant mice were ovariectomized between 15.00 and 18.00 hours on Day 3 of pregnancy and received progesterone $1.0 \mathrm{mg} /$ day until killed. Results are expressed as the percentage of mice with implants or blastocysts on Day 10, and the mean numbers present in these mice.

* Mean numbers in parentheses.

TABLE 2

ATTEMPTED INHIBITION OF OESTRADIOL-INDUCED IMPLANTATION IN OVARIEGTOMIZED MICE

\begin{tabular}{|c|c|c|c|c|c|c|c|}
\hline Treatment & $\begin{array}{c}\text { Daily } \\
\text { dose }\end{array}$ & $D a y(s)$ & $\begin{array}{c}\text { No. of } \\
\text { mice }\end{array}$ & \multicolumn{2}{|c|}{$\begin{array}{l}\% \text { with } \\
\text { blastocysts }\end{array}$} & \multicolumn{2}{|c|}{$\begin{array}{l}\% \text { with } \\
\text { implants }\end{array}$} \\
\hline $\begin{array}{l}\text { Saline } \\
\text { Compound 48/80 } \\
\text { Polymyxin B } \\
\text { Histamine diphosphate } \\
\text { Saline } \\
\text { Mepyramine } \\
\text { Cortisol } \\
\text { Cortrophin } \mathrm{ZN} \\
\text { Saline } \\
\text { Mepyramine } \\
\text { Cortisol } \\
\text { Cortrophin ZN }\end{array}$ & $\begin{array}{r}0.1 \mathrm{ml} \\
50.0 \mu \mathrm{g} \\
100.0 \mu \mathrm{g} \\
250.0 \mu \mathrm{g} \\
0.1 \mathrm{ml} \\
1.0 \mathrm{mg} \\
1.0 \mathrm{mg} \\
1.0 \mathrm{i.u} \\
0.1 \mathrm{mg} \\
1.0 \mathrm{mg} \\
1.0 \mathrm{ml} \\
1.0 \text { i.u. }\end{array}$ & $\begin{array}{l}4 \text { to } 6 \\
4 \text { to } 6 \\
4 \text { to } 6 \\
4 \text { to } 6 \\
6 \\
6 \\
6 \\
6 \\
6 \text { to } 9 \\
6 \text { to } 9 \\
6 \text { to } 9 \\
6 \text { to } 9\end{array}$ & $\begin{array}{r}20 \\
12 \\
10 \\
10 \\
10 \\
8 \\
10 \\
8 \\
15 \\
8 \\
11 \\
11\end{array}$ & $\begin{array}{c}10 \\
8 \cdot 4 \\
20 \\
0 \\
10 \\
0 \\
0 \\
0 \\
0 \\
0 \\
0 \\
0\end{array}$ & $\begin{array}{l}(3 \cdot 0)^{*} \\
(5 \cdot 0) \\
(1 \cdot 5) \\
(0 \cdot 0) \\
(2 \cdot 0) \\
(0.0) \\
(0 \cdot 0) \\
(0.0) \\
(0 \cdot 0) \\
(0.0) \\
(0.0) \\
(0.0)\end{array}$ & $\begin{array}{l}70 \\
66 \cdot 7 \\
70 \\
70 \\
90 \cdot 6 \\
100 \\
75 \\
100 \\
66 \cdot 7 \\
100 \\
100 \\
100\end{array}$ & $\begin{array}{l}(13 \cdot 6)^{*} \\
(9 \cdot 6) \\
(10 \cdot 3) \\
(9 \cdot 3) \\
(8 \cdot 3) \\
(10 \cdot 8) \\
(12 \cdot 7) \\
(9 \cdot 1) \\
(7 \cdot 2) \\
(15 \cdot 6) \\
(7 \cdot 5) \\
(8 \cdot 6)\end{array}$ \\
\hline
\end{tabular}

Ovariectomized, progesterone-treated pregnant mice received $0.025 \mu \mathrm{g}$ of oestradiol at 12.00 hours on Day 6 to induce implantation. Various substances were given before or after induction, as described in the text.

Results are expressed as the percentages of mice with implants or blastocysts on Day 10, and the mean numbers present in these animals.

* Mean numbers in parentheses.

treated or histamine-depleted animals are conflicting. Humphrey (1966) found that the induction of deciduomata in intact rats and ovariectomized mice was not prevented by histamine depletion, while Banik et al. (1963) 
showed that injections of histamine or compound $48 / 80$ on Days 1 to 6 of pregnancy did not prevent implantation in rats but were partly effective in mice.

This is in contrast to the results of Kraicer, Marcus \& Shelesnyak (1963) who reported that repeated injections of near-toxic doses of compound $48 / 80$ or pyrathiazine would almost completely prevent the induction of deciduomata by systemic pyrathiazine in intact rats. Decidualization after crushing, or implantation was less readily inhibited.

These conflicting reports may reflect non-specific or toxic actions of histamine liberators or histamine on the events of early pregnancy or pseudopregnancy. The doses of compound 48/80 used by Banik et al. (1963) and Kraicer et al. (1963) are several times larger than those used by Riley (1959) to achieve almost maximal possible depletion of tissue histamine in mice and rats. Paton (1957) has reported the direct effects of such large doses of compound 48/80, and has pointed out that histamine depletion is not a harmless procedure to the animal. Several drugs related to pyrathiazine also affect the release of pituitary-gonadotrophins (Zarrow \& Brown-Grant, 1964).

Bovet-Nitti, Bignami \& Bovet (1963) found that mepyramine prevented implantation in about $50 \%$ of rats, but attributed this to an action on the central nervous system, and not to antagonism of histamine. In the present experiments, mepyramine did not interfere with implantation or early embryogenesis in ovariectomized animals.

Meyer \& Cochrane (1962) showed that cortisone did not induce implantation in ovariectomized rats-a finding confirmed here with cortisol and ACTH in mice. Cortisol will antagonize the stimulatory effects of oestradiol on water uptake and growth in the rat uterus (Spaziani, 1963). The first sign of oestradiol-induced implantation in the mouse is a local increase in vascularity and capillary permeability under the blastocyst (Humphrey, unpublished observations), but neither cortisol nor ACTH affected oestradiol-induced implantation or embryonic growth in the present work.

From these results and those of Humphrey (1966), it is concluded that histamine and mast cell factors are not important in decidualization.

\section{REFERENCES}

Banik, U. K., Kobayashi, Y. \& Ketchel, M. M. (1963) Effect of aminoguanidine, histamine, histidine and Compound 48/80 on pregnancy in rats and mice. F. Reprod. Fert. 6, 179.

Bovet-Nrti, F., Bignami, G. \& Bovet, D. (1963) Antihistamine drugs on rat pregnancy: Effect of Pyrilamine and Meclizine. Life Sci. No. 5, 303.

Humphrey, K. W. (1966) The actions of hormones and antihormones on the female reproductive tract. Ph.D. thesis, University of Sydney.

Humphrey, K. W. (1967) The development of viable embryos after ovum transfers to long term ovariectomized mice. Steroids, 9, 53.

Kraicer, P. F., Marcus, G. J. \& Shelesnyak, M. G. (1963) Decidualization in the histamine-depleted rat. F. Reprod. Fert. 5, 417.

MEYER, R. K. \& CochRANE, R. L. (1962) Induction of implantation in the ovariectomized progesteronetreated rat after adrenalectomy. F. Endocr. 24, 77.

Paton, W. D. M. (1957) Histamine release by compounds of simple chemical structure. Pharmac. Rev. 9, 269.

Psychoyos, M. A. (1961) Nouvelles recherches sur l'ovoimplantation. C.r. hebd. Séanc. Acad. Sci., Paris, 252, 2306. 
RILEY, J. F. (1959) The mast cells. Livingstone, Edinburgh.

SHELESNYAK, M. C. (1963) Interdisciplinary approaches to the endocrinology of reproduction. In: Techniques in Endocrine Research, p. 231. Eds. P. Eckstein and F. Knowles. Academic Press, New York.

Spaziani, E. (1963) Relationship between early vascular responses and growth in the rat uterus: stimulation of cell division by estradiol and vasodilating amines. Endocrinology, 72, 180.

Zarrow, M. X. \& Brown-Grant, K. (1964) Inhibition of ovulation in the gonadotrophin-treated immature rat by chlorpromazine. F. Endocr. 30, 87. 